\title{
SURVEY OF INDIANA ADMINISTRATIVE LAW
}

\author{
TABITHA L. BALZER" \& MANUEL “MANNY” HERCEG**
}

INTRODUCTION $^{* * *}$

Administrative agencies regulate a wide breadth of issues - including driver's licenses, alcoholic beverage permits, placement of utility poles, administration of the state's Medicaid program, and complaints by prisoners - to name just a few examples discussed in this Article. These agencies form a bridge between Indiana's citizens and their government. The purpose of this survey Article, as in years past, is to highlight a few significant decisions by Indiana appellate courts over the last year (October 2016-September 2017) concerning administrative law issues that have far-reaching effect.

\section{ACCESS TO JUDICIAL REVIEW}

\section{A. Procedural Issues Concerning Petitions for Judicial Review}

The rules governing the review of agency actions are not immune from the issues present in all litigation, and particularly regarding errors in filing. Hunter v. State Department of Transportation ${ }^{1}$ presents a straightforward application of a longstanding rule; viz. an untimely filing of a petition for judicial review is a procedural error. However, unlike the application of Appellate Rule 9(A) generally, the Administrative Orders and Procedures Act (AOPA) does not permit the showing of "good cause" to excuse the untimely filing. ${ }^{2}$

The Indiana Department of Transportation (INDOT) terminated Hunter. After exhausting his administrative remedies, Hunter sought judicial review of the final agency action upholding his termination. ${ }^{3}$ However, Hunter was a day late in filing his petition for judicial review under Indiana Code section 4-21.5-5-5, which provides that "[e]xcept as otherwise provided, a petition for review is timely only if it is filed within thirty (30) days after the date that notice of the agency action that is the subject of the petition for judicial review was served." INDOT filed a response to Hunter's petition, and then subsequently filed a motion to dismiss the petition for failure to state a claim under Indiana Trial Rule

* Tabitha Balzer is a director at Lewis Kappes P.C., where she focuses on utility law and commercial litigation. She is a graduate of Indiana University and Indiana University Maurer School of Law.

** Manny Herceg is an attorney at the Indianapolis office of Taft Stettinius \& Hollister LLP where he focuses his practice on civil litigation, multi-district litigation, and municipal law. He is a graduate of Indiana University and the Indiana University Robert H. McKinney School of Law.

*** The authors would like to thank Alexander Carlisle, an attorney at Lewis Kappes P.C., for his assistance with this Article.

1. 67 N.E.3d 1085 (Ind. Ct. App. 2016).

2. IND. CODE $\S 4-21.5-1-1$ through IND. CODE $§ 4-21.5-7-9$ (2017).

3. Hunter, 67 N.E.3d at 1087.

4. $I d$. 
12(b)(6) - an argument it failed to raise in its initial response. ${ }^{5}$ The trial court granted INDOT's motion to dismiss. ${ }^{6}$ Hunter filed a motion to correct error, which the trial court denied. ${ }^{7}$ On appeal, Hunter focused on two arguments. First, Hunter asserted that untimeliness was an affirmative defense and, because INDOT failed to raise it in its initial response, it failed to preserve the issue for the motion to dismiss. ${ }^{8}$ Second, he argued that because his failure to file the petition timely was a procedural error, he should be afforded an opportunity to demonstrate good cause to excuse the untimely filing.'

The court of appeals was unconvinced. Addressing the first argument, the court noted that even if "Hunter is correct, the trial court nevertheless could have considered the issue and found that he waived his right to judicial review pursuant to Indiana Code section 4-21.5-5-4(b)." ${ }^{10}$ As for the second argument, the court held that Indiana Code section 4-21.5-5-4(b) provides that failure to file a timely petition results in waiver of judicial review. Because AOPA "establishes the exclusive means for judicial review of an agency action" the court found that (unlike the application of Appellate Rule 9(A) generally), "there is no mechanism allowing the trial court to resurrect a waived right to judicial review." result, the court upheld the dismissal of Hunter's petition.

\section{B. Standing}

21st Amendment, Inc. v. Indiana Alcohol \& Tobacco Commission ${ }^{12}$ presents an interesting issue of standing under the Administrative Orders and Procedures Act (AOPA) as it relates to a claim for relief (and standing) under a separate statute: namely, whether an entity has standing to intervene in the permit application process of a competitor. ${ }^{13} 21$ st Amendment remonstrated against LD Ventures, Inc. $\mathrm{d} / \mathrm{b} / \mathrm{a}$ Grapevine Cottage's petition to renew an alcoholic beverage permit as a "specialty or gourmet food store" claiming that Grapevine Cottage is ineligible for the permit because it "does not primarily engage in the sale of specialty foods as statutorily required." 14 Despite 21st Amendment's remonstrance, the local board approved Grapevine Cottage's application. 21st Amendment objected, petitioned to intervene, and filed a request for appeal with the Indiana Alcohol and Tobacco Commission. ${ }^{15}$ The Commission denied the petition to intervene, and 21st Amendment filed a petition for judicial review

\footnotetext{
5. Id.

6. $I d$.

7. $I d$.

8. Id. at 1090 .

9. Id.

10. Id.

11. Id. at 1091.

12. 84 N.E.3d 691 (Ind. Ct. App. 2017).

13. Id.

14. Id. at 694.

15. Id.
} 
claiming it was "directly impacted and aggrieved or adversely affected by the agency's actions" and because it is "a permittee with a statutory right to abate a nuisance." $" 16$ The Commission filed a motion to dismiss the petition for judicial review arguing that 21st Amendment is barred from seeking judicial review and, even if not barred, it lacks standing to seek judicial review. ${ }^{17}$ The trial court granted the Commission's motion to dismiss, finding that:

21st Amendment cannot seek to abate a public nuisance on petition for judicial review .... Abating a public nuisance is not a petition for judicial review. Rather, it is a separate cause of action that allows several individuals, including ... permittee, to enjoin an act, practice, or manner of conducting business by a permittee or by a non-permittee that is contrary [to] a rule or regulation . . . . ${ }^{18}$

On appeal, the court reviewed whether 21st Amendment had standing under AOPA, which specifies that "only parties who have standing are entitled to judicial review of a final agency action." ${ }^{19}$ And the question here involves a separate nuance because of 21 st Amendment's position as an intervening remonstrator. Specifically, under AOPA, "a person must be aggrieved or adversely affected in order to seek administrative review as an intervening remonstrator." ${ }^{20}$ So, in this case, the court had to evaluate whether $21 \mathrm{st}$ Amendment has standing and whether it exhausted administrative remedies. The court noted that 21 st Amendment petitioned to be an intervening remonstrator and requested an administrative appeal. The Commission denied its petition to intervene because, in part, it did not view 21 st Amendment as "adversely affected or aggrieved." 21 21st Amendment, however, claimed that it had standing under the public nuisance statutes. ${ }^{22}$

Hence, the issue before the court, at its essence, was whether $21 \mathrm{st}$ Amendment had standing to seek judicial review under the public nuisance statutes under Indiana Code section 4-21.5-5-3(a)(3), "which accords standing for judicial review if the party has standing under a law applicable to the final agency action." 23

The court was unconvinced of 21st Amendment's argument. Turning to the relevant statutory language, Title 7.1 of the Indiana Code governing alcohol and tobacco, the court noted that there are provisions that violations of the law or a rule of the Commission may be declared a public nuisance. ${ }^{24}$ Yet, ultimately, $21 \mathrm{st}$ Amendment did not have standing because there was no final agency action that

16. Id.

17. Id.

18. Id. at 695.

19. Id.

20. Id. at 696 (internal quotations omitted).

21. Id.

22. Id.

23. Id. (internal quotations omitted).

24. Id. at 697. 
would give rise to standing under Indiana Code section 4-21.5-5-3(a)(3). Indeed, as the court observed, "as the public nuisance statutes establish, it is the conduct of the permittee ... or conduct otherwise carried on in premises where alcoholic beverages are kept/sold that may give rise to a public nuisance claim. ${ }^{" 25}$ As such, the "alleged nuisance is not the result of the agency's action, but rather the subsequent conduct of the permittee" and 21st Amendment does not have standing "under a law applicable to the final agency action." 26

Therefore, 21st Amendment makes clear that the court will look to the plain meaning of AOPA and relied on the long-standing rule that any action for judicial review must be preceded by a final agency action. ${ }^{27}$

\section{Exhaustion of Administrative Remedies}

An individual or entity aggrieved by the actions or inactions of the state must generally exhaust administrative remedies before seeking court intervention. ${ }^{28}$ That is true even if the agency action is alleged to be ultra vires and void. ${ }^{29}$ In determining whether exhaustion of administrative remedies is required, it is the substance of a cause of action that governs, not the manner in which the parties characterize their requests for relief. ${ }^{30}$ As such, when an administrative remedy is available, courts are reluctant to permit a claimant to proceed on a different, non-administrative, legal theory. ${ }^{31}$ Furthermore, though most recent case law has held that failure to exhaust is a procedural error that does not implicate subject matter jurisdiction, one 2017 case (quoting earlier precedent) connected subject matter jurisdiction to a requirement that the administrative agency resolve all factual issues. ${ }^{32}$

1. Substance of Claim Controls Whether Exhaustion of Administrative Remedies Is Required.-Indiana Bureau of Motor Vehicles v. Watson ${ }^{33}$ illustrated the principle that the substance of a cause of action governs whether exhaustion of administrative remedies is required, not the manner in which petitioners characterize their requests for relief. ${ }^{34}$ The case also addressed the legal effect of failure to serve the Attorney General. ${ }^{35}$

Watson involved the request for the renewal of a chauffeur's license by a driver (Watson) in connection with his employment in the construction industry,

25. Id. at 698 .

26. Id.

27. $I d$.

28. IND. CoDE §4-21.5-5-4(a) (2017).

29. See generally Johnson v. Celebration Fireworks, Inc., 829 N.E.2d 979 (Ind. 2005).

30. See generally Ellis v. State, 58 N.E.3d 938 (Ind. Ct. App. 2016) and Bragg v. Kittle's Home Furnishing, Inc., 52 N.E.3d 908 (Ind. Ct. App. 2016).

31. See generally Celebration Fireworks, Inc., 829 N.E.2d 979.

32. See generally Ellis, 58 N.E.3d 938.

33. 70 N.E. $3 d 380$ (Ind. Ct. App. 2017).

34. $I d$.

35. Id. 
where he had been working for approximately twenty-five years. ${ }^{36}$ In 2000 , Watson's driver's license had been suspended by the state of Illinois for failure to make required payments towards fines and costs. ${ }^{37}$ Though eligible for reinstatement of his Illinois license, Watson instead elected to move to Indiana, where he obtained a driver's license in 2001 that was subsequently amended to a chauffeur's license. ${ }^{38}$ Watson's chauffeur's license was renewed in 2005 and 2009, but the renewal was denied in 2015 due to the Illinois suspension. ${ }^{39}$ The BMV based its decision on the Driver License Compact Act, enacted by both Illinois and by Indiana ${ }^{40}$ pursuant to Indiana Code section 9-28-1-3. The BMV instructed Watson that his Illinois suspension would need to be resolved before he could renew his Indiana license. ${ }^{41}$ Watson administratively appealed the BMV's decision, but the BMV ultimately issued a final order on December 21, 2015 upholding the denial of the license renewal. ${ }^{42}$

A week later, on December 28, 2015, Watson filed a Verified Petition for Special Driving Privileges in Lake County Circuit Court. ${ }^{43}$ The trial court held a hearing, at which the Lake County deputy prosecutor appeared on behalf of the $\mathrm{BMV}$, and the court granted Watson's request for special driving privileges. ${ }^{44}$ However, the following month, the BMV sent the court a note stating that it could not issue the special driving privileges due to the Illinois suspension. ${ }^{45}$

Watson responded by filing a Motion to Compel Issuance of Specialized Driving Privileges or to Issue a Valid Driver's License Credential ("Motion to Compel") requesting the trial court to order the BMV to issue him special driving privileges ${ }^{46}$ He served the Motion to Compel on the Commissioner of the Bureau of Motor Vehicles and the Lake County Prosecuting Attorney's Office. ${ }^{47}$ After a hearing, the court agreed with Watson that the BMV had misapplied the Driver License Compact Act, found that the BMV was equitably estopped from refusing to renew the chauffeur's license, and ordered the BMV to issue Watson a chauffeur's license. ${ }^{48}$

The Attorney General of Indiana ("AG") subsequently intervened and filed a motion to correct error. ${ }^{49}$ The AG contended that because Watson's request was

36. Id. at $382-83$.
37. Id. at 382.
38. Id. at $382-83$.
39. Id. at 383.
40. Id.
41. Id.
42. Id.
43. Id.
44. Id.
45. Id.
46. Id.
47. Id.
48. Id.
49. Id. 
essentially a petition for judicial review, service upon the AG was required ${ }^{50}$ It reasoned that because no such service was made, the trial court never obtained personal jurisdiction over the BMV. ${ }^{51}$ The trial court denied the motion to correct error, and the BMV appealed. ${ }^{52}$

The court of appeals found that, in ruling on Watson's Motion to Compel, the trial court had engaged in judicial review of an agency decision. ${ }^{53}$ The label Watson used to describe his motion was not controlling; rather, the court looked at the substance of the motion and determined that it challenged the BMV's decision not to issue him a license as well as the BMV's interpretation of the relevant statute. ${ }^{54}$ The court concluded that because Watson's Motion to Compel was effectively a petition to the trial court for judicial review of the BMV's decision, Watson was required to comply with AOPA. ${ }^{55}$

The court explained that though AOPA is the "exclusive means for judicial review of an agency action" pursuant to Indiana Code section 4-21.5-5-1, there are nevertheless some exceptions to this statute. ${ }^{56}$ One such exception is a statutory amendment that became effective July 2016 and exempts challenges to BMV actions taken under Title 9, Article 28 (which includes the Driver License Compact Act) from judicial review under AOPA. ${ }^{57}$ The statute instead provides that administrative review procedures under Indiana Code section 9-33-2-3 apply. ${ }^{58}$ Watson argued that the new statute should be applied retroactively, but the court of appeals disagreed, determining that the legislature did not express unequivocal and unambiguous intent for retrospective effect of the statutory amendments. ${ }^{59}$ The court further indicated that even if the amendments were applied retroactively, such application would not have helped Watson. Watson did not comply with the procedures of Title 9 Article 33, which (like AOPA) also required service on the AG. ${ }^{60}$

The BMV and Watson disagreed regarding whether Watson's failure to serve the AG resulted in lack of personal jurisdiction over the BMV. The BMV cited to Guy v. Commissioner, Indiana Bureau of Motor Vehicles ${ }^{61}$ which found that no personal jurisdiction over the BMV was obtained after only the BMV Commissioner was served, and no one appeared for the Commissioner at the

50. Id.

51. Id. at 383-84.

52. Id. at 383 .

53. Id. at 385 .

54. Id.

55. Id.

56. Id.

57. Id.

58. Id. The previous year, in 2015, Title 9, Article 33 had been amended to exempt other types of actions from AOPA, and instead required that the procedures outlined in IND. CODE $\S 9$ 33-2-3 be followed. Id. These 2015 amendments did not originally apply to Title 9, Article 28. Id.

59. Id.

60. Id. at 385-86.

61. 937 N.E.2d 822 (Ind. Ct. App. 2010). 
hearing. Watson cited to Evans v. State, ${ }^{62}$ which found that personal jurisdiction over FSSA was obtained when summonses were sent to the Governor at the Indiana Statehouse and to the AG, both naming the State and FSSA as respondents, and a deputy AG had entered an appearance requesting an extension of time. The Evans court held that although FSSA should have been served instead of the AG, dismissal for lack of personal jurisdiction was not warranted ${ }^{63}$ That court explained that Indiana Trial Rule $4.15(\mathrm{~F})$ provides that a summons/service should not be set aside or judged insufficient when either "is reasonably calculated to inform the person to be served that an action has been instituted against him, the name of the court, and the time within which he is required to respond." ${ }^{64}$ Because the deputy AG had entered an appearance, the FSSA had actual notice and the summons was reasonably calculated to inform the FSSA of the lawsuit. ${ }^{65}$

The court of appeals found that Watson's case was more akin to Guy than Evans, even though a deputy prosecutor had appeared on behalf of the BMV. ${ }^{66}$ The court explained that the deputy prosecutor was already required to appear on behalf of the BMV to address Watson's petition for special driving privileges, and that the prosecuting attorney is not charged with defending judicial review of an agency action. ${ }^{67}$ The court also expressed concern over the deputy prosecutor's lack of significant participation in the hearing on Watson's Motion to Compel. ${ }^{68}$

The court concluded that because Watson's Motion to Compel was essentially a request for judicial review, he was required to comply with AOPA, including its requirement of service on the AG. ${ }^{69}$ Because the $\mathrm{AG}$ was not served, the trial court never obtained personal jurisdiction over the BMV to order the BMV to issue Watson a chauffeur's license. ${ }^{70}$

Similarly, Shoemaker v. Indiana State Police Department ${ }^{71}$ demonstrated that a party cannot circumvent the relevant administrative procedure by instead filing a complaint for declaratory relief in state court. ${ }^{72}$ That case involved the

62. 908 N.E.2d 1254 (Ind. Ct. App. 2009).

63. Id. at 1258 .

64. Id.

65. Id. at 1259.

66. Ind. Bureau of Motor Vehicles v. Watson, 70 N.E.3d 380, 387 (Ind. Ct. App. 2017).

67. Id.

68. Id. at 387 . The court of appeals noted that the deputy prosecutor's "only participation in the hearing involved a colloquy that went as follows:

[The State]: Nothing from the State.

The Court: So ..., you're representing the BMV?

[The State]: I believe so."

Id. at $383 \mathrm{n} 1$.

69. Id. at 387-88.

70. Id. at 388 .

71. 62 N.E.3d 1242 (Ind. Ct. App. 2016), trans. denied, 80 N.E.3d 180 (Ind. 2017).

72. Id. at 1243. 
complaint of Shoemaker, a longtime law enforcement officer with the Indiana State Police Department ("ISP") who was demoted in rank and pay shortly after a new Superintendent of the ISP was appointed. ${ }^{73}$ Shoemaker sought administrative review with the State Employees Appeals Commission ("SEAC") pursuant to the Whistleblower Act ("WBL"). ${ }^{74} \mathrm{He}$ alleged that the demotion was the result of a whistleblower report he had filed four years previously, which detailed problems he had observed while a sergeant in the Drug Enforcement Section of the Criminal Investigation Division, including ghost employment, overtime, and possible misrepresentations by law enforcement officers to the court. $^{75}$

Shoemaker argued that although his complaint was filed over nine months after his demotion, the thirty-day statute of limitation should be stayed based on equitable tolling and fraudulent concealment. ${ }^{76}$ The ALJ rejected this argument, finding that his complaint was untimely and that equitable tolling based on fraudulent concealment did not apply to save his action. ${ }^{77}$ The ALJ advised him that he could seek judicial review of the decision within thirty days ${ }^{78}$ However, rather than exhaust this administrative remedy, Shoemaker instead filed a complaint for breach of contract in Marion County Superior Court based on the ISP's alleged violation of the WBL. ${ }^{79}$ The trial court granted ISP's motion for summary judgment, and Shoemaker appealed. ${ }^{80}$

On appeal, Shoemaker claimed that futility excused his failure to exhaust administrative remedies. ${ }^{81}$ Shoemaker pointed out that the SEAC did not apply to him pursuant to Indiana Code section 4-15-2.2-1(b)(7), which defines the general applicability of the chapter and expressly excludes ISP. ${ }^{82}$ Because the WBL's administrative remedy statute ${ }^{83}$ invokes the SEAC's administrative appeal process, ${ }^{84}$ Shoemaker reasoned that the WBL's administrative review process did not apply to him. ${ }^{85}$

In rejecting Shoemaker's argument, ${ }^{86}$ the court of appeals first restated its

73. $I d$.

74. Id. at $1243-44$.

75. Id. at 1244 .

76. $I d$.

77. Id.

78. Id.

79. Id.

80. Id.

81. Id. at 1246.

82. Id. at $1246-47$.

83. IND. CODE $\S 4-15-10-4$ (c) (2017).

84. Id. § 4-15-2.2-42.

85. Shoemaker, 62 N.E.3d at 1246.

86. Before reaching the merits of Shoemaker's case, the court of appeals addressed a procedural defect in Shoemaker's case: his failure to provide an adequate record on appeal. Id. at 1245. The court noted that because Shoemaker bears the burden of showing that the grant of summary judgment was inaccurate, the court would be within its discretion to conclude that he 
previous holding that the administrative appeals process provided for in the WBL is a mandatory prerequisite to judicial review. ${ }^{87}$ The court explained that, "If we were to hold that a claimant could seek judicial review based on a right derived from the WBL through common law and, therefore, bypass the exhaustion of administrative remedies requirement of the WBL, it would make the exhaustion requirements of the WBL illusory." 88 The court reiterated the familiar requirement that one claiming futility must show "that the administrative agency was powerless to effect a remedy or that it would have been impossible or fruitless and of no value under the circumstances" along with the familiar caution that "the exhaustion requirement is much more than a procedural hoop and that it should not be dispensed with lightly on the grounds of "futility." pointed out that Shoemaker's contention that the SEAC did not apply to him contradicted the arguments he had previously made when the case was before the ALJ, as well as his previous actions, insofar as he had already completed the first three steps of the SEAC judicial review process. ${ }^{90}$ The court then examined the relationship of the SEAC and the WBL, and concluded that the WBL brings the SEAC into its ambit for the limited purpose of applying the SEAC review process, even for employees otherwise excluded from the SEAC pursuant to Indiana Code section 4-15-2.2-1(b). ${ }^{91}$

Shoemaker also claimed that he had no obligation to exhaust administrative remedies because the statute conferred a contractual right entitling him to bring a breach of contract action, relying exclusively on Whinery $v$. Roberson, 819 N.E.2d 465 (Ind. Ct. App. 2006). ${ }^{92}$ In Whinery, employees of the Indiana Department of Natural Resources sued the Director of State Personnel Department for failure to comply with the salary statute. ${ }^{93}$ The court in that case concluded that the employees could sue for a violation of employment rights in contract despite being employed at-will, because "a government employee's relationship with the State, although not necessarily defined by a written employment contract, is 'purely contractual.","94

The court of appeals rejected this argument as well, finding Whinery distinguishable because the WBL does not address anything along the lines of remuneration or tenure. ${ }^{95}$ The court also found that "[m]ore importantly, the WBL

failed to present a record sufficient to conclude that the trial court erred. Id. However, the court noted that it prefers to decide cases on the merits when possible, and that its review, though "significantly hampered" was possible because ISP filed the omitted portions of the record in its appendix. $I d$.

87. Id. at 1246.

88. Ogden v. Robertson, 962 N.E.2d 134 (Ind. Ct. App. 2012).

89. Town Council of New Harmony v. Parker, 726 N.E.2d 1217, 1224 (Ind. 2000).

90. Shoemaker, 62 N.E.3d at 1246, 1248.

91. Id. at 1248.

92. Id. at 1246.

93. Id. at 1249 .

94. Id. (quoting Whinery v. Roberson, 819 N.E.2d 465, 473 (Ind. Ct. App. 2006)).

95. Id. 
provides an express remedy for an alleged violation of the statute through an SEAC administrative appeal," and that Whinery does not provide the right "to avoid the administrative steps and turn directly to the courts by filing a breach of contract claim based on an alleged violation of the WBL." 96

In conclusion, the court of appeals held that "a state employee seeking redress for an employment action allegedly taken in retaliation for whistleblowing activity must proceed with, and only with, the remedy expressly provided in the WBL." $" 97$

2. Requirement of Exhaustion When Agency Action Is Allegedly Ultra Vires and Void.-Like Shoemaker and Watson, First American Title Insurance Co. v. Robertson ${ }^{98}$ addressed the prohibition against circumventing agency authority by proceeding under a different statutory theory. In addition, the case also addressed the requirement of exhaustion when an agency action is alleged to be ultra vires and void, as well as the implications of res judicata..$^{99}$ In a previous case, First American Title Company ("FATIC") had challenged an order of the Indiana Department of Insurance ("IDOI") in scheduling a hearing to investigate FATIC's market conduct. ${ }^{100}$ The IDOI had retained a third party to orchestrate a market conduct examination report, and was statutorily required to issue the order setting the hearing within thirty days after the end of the period allowed for the receipt of written submissions or rebuttals to the report. ${ }^{101}$ IDOI failed to meet this deadline. ${ }^{102}$ After granting IDOI two retroactive extensions of time to issue its order, FATIC objected to the IDOI's third retroactive request for extension of time. ${ }^{103}$ The IDOI issued an order scheduling the hearing anyway, and FATIC filed a petition for judicial review and declaratory relief with the trial court. ${ }^{104}$ FATIC argued that the IDOI's order was void as untimely, and submitted only documents on this issue, rather than the complete agency record. ${ }^{105}$ IDOI argued that FATIC's case should be dismissed due to its failure to file the complete agency record. ${ }^{106}$ The first case ultimately went to the Indiana Supreme Court, which determined, in relevant part to the present case, ${ }^{107}$ that because FATIC

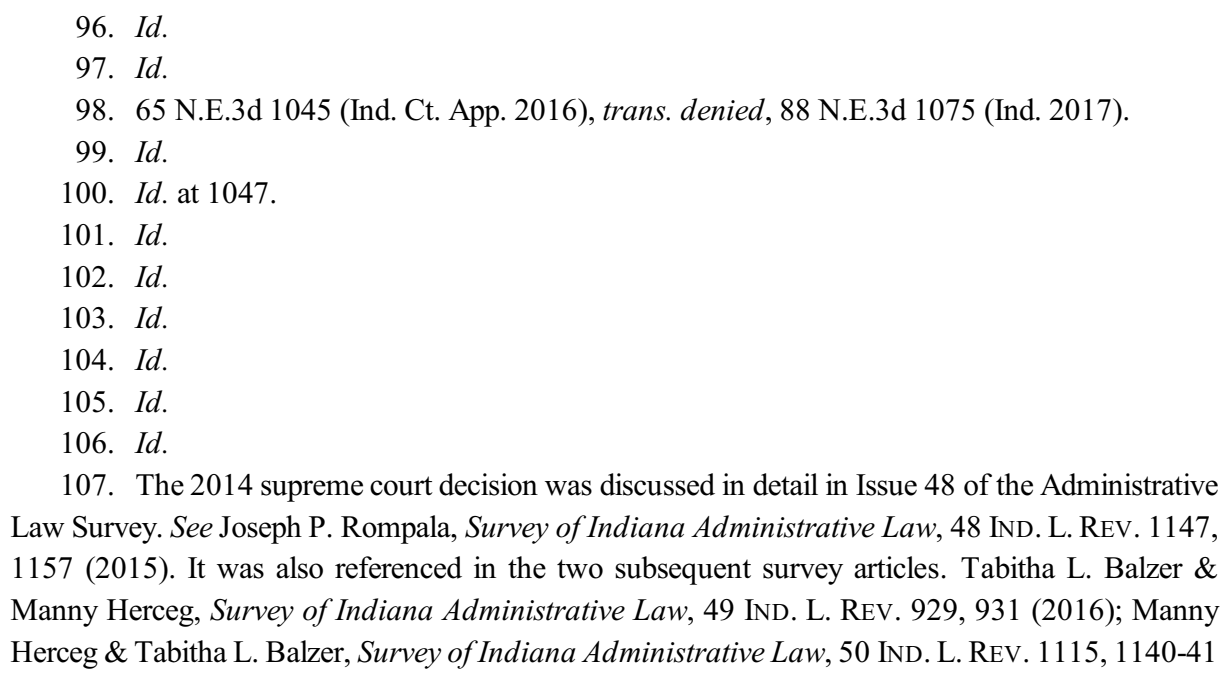
1157 (2015). It was also referenced in the two subsequent survey articles. Tabitha L. Balzer \& Manny Herceg, Survey of Indiana Administrative Law, 49 IND. L. REv. 929, 931 (2016); Manny Herceg \& Tabitha L. Balzer, Survey of Indiana Administrative Law, 50 IND. L. REV. 1115, 1140-41 
failed to file the complete agency record with the trial court, its petition for judicial review should not be considered. ${ }^{108}$ The first supreme court decision had also included a footnote upholding the court of appeals' determination that the IDOI's order was untimely and void. ${ }^{109}$ However, this footnote language was subsequently stricken on rehearing as contradictory to the supreme court's finding that FATIC's case should be dismissed for failure to file the complete record. ${ }^{110}$ The supreme court also summarily upheld the court of appeals' finding that failure to exhaust administrative remedies raises a waivable procedural error, not an un-waivable jurisdictional one, and that IDOI had waived this argument by raising it for the first time on appeal. ${ }^{11}$

On remand to the trial court, FATIC filed a "Writ of Prohibition and Action for Mandate, Request for Declaratory Relief, and Verified Amended Petition for Judicial Review." ${ }^{12}$ In requesting declaratory relief, FATIC maintained that an administrative agency's void action is subject to collateral attack at any time. ${ }^{113}$ IDOI moved to dismiss the case, arguing that AOPA was FATIC's exclusive remedy and that the supreme court had already found that its AOPA claim failed. ${ }^{114}$ IDOI also argued that FATIC could not bring an AOPA claim dressed as a declaratory judgment action and that FATIC's claims were barred by res judicata and the law of the case doctrine. ${ }^{115}$ The trial court granted IDOI's motion to dismiss, finding it barred by res judicata. ${ }^{116}$ The court also determined that AOPA was FATIC's exclusive means for judicial review of IDOI's actions, and that because FATIC had an administrative remedy, FATIC could not bring declaratory judgment and mandate claims on the same issue. ${ }^{117}$

On appeal, FATIC contended that its claim was not barred by res judicata, because FATIC had raised the issue of whether the IDOI's action was void in the previous case, but the supreme court chose not to resolve it. ${ }^{118}$ FATIC argued that res judicata only bars issues actually decided. ${ }^{119}$

In contending that res judicata did not bar his declaratory action claim because that claim was not actually litigated and decided, FATIC relied on concepts applicable to issue preclusion. ${ }^{120}$ The court of appeals instead found that

(2017)

108. Robertson., 65 N.E.3d at 1048.

109. Id. at 1048-49.

110. Id. at 1049.

111. Id. at 1048 .

112. Id.

113. Id.

114. $I d$.

115. Id.

116. Id.

117. Id.

118. Id. at $1050-51$.

119. Id. at 1051 .

120. Issue preclusion (aka collateral estoppel) bars subsequent re-litigation of the same fact or issue in a subsequent suit and applies even if the second adjudication is on a different claim. 
claim preclusion barred his action. ${ }^{121}$ The court noted although FATIC's first action included both a petition for judicial review and a declaratory judgment action, FATIC made no specific arguments about his request for declaratory relief before either the court of appeals or the supreme court. ${ }^{122}$ The court concluded that FATIC's second action "is merely asserting the same claim that our supreme court previously rejected due to FATIC's failure to file the entire agency record." 123 The court noted that claim preclusion bars "all matters that were or might have been litigated," 124 and thus implicitly distinguished the scope of claim preclusion from the more limited scope of issue preclusion (applicable only to bar issues actually litigated and decided). ${ }^{125}$ Because claim preclusion does not bar a different cause of action arising from the same occurrence, ${ }^{126}$ the court of appeals' finding that FATIC's declaratory judgment action was the same claim as his AOPA action was critical to its determination that claim preclusion barred FATIC's declaratory judgment action. ${ }^{127}$

In addition, FATIC contended that it was not required to exhaust its administrative remedies before bringing a declaratory judgment action because

Thrasher Buschmann \& Voelkel, P.C. v. Adpoint, Inc., 24 N.E.3d 487, 494 (Ind. Ct. App. 2015); Nat'l Wine \& Spirits, Inc. v. Ernst \& Young, LLP, 976 N.E.2d 699, 704 (Ind. 2012). Issue preclusion only applies where the fact or issue was necessarily adjudicated in the previous lawsuit, not to all matters that could have been decided. Nat'l Wine \& Spirits, Inc., 976 N.E.2d at 704; Miller Brewing Co. v. Ind. Dep't of State Revenue, 903 N.E.2d 64, 68 (Ind. 2009); Conn. Indem. Co. v. Bowman, 652 N.E.2d 880, 883 (Ind. Ct. App. 1995).

121. Robertson, 65 N.E.3d at 1050, 1052. Claim preclusion applies where a final judgment on the merits has been rendered, and acts as a complete bar to a subsequent litigation on the same issue or claim. Indianapolis Downs, LLC v. Herr, 834 N.E.2d 699, 703 (Ind. Ct. App. 2005), trans. denied, 855 N.E.2d 994 (Ind. 2006). Claim preclusion bars all matters that were or might have been litigated, but does not bar a separate cause of action arising from the same occurrence. Id.

122. Robertson, 65 N.E.3d at 1052 .

123. Id.

124. Id.

125. Nat'l Wine \& Spirits, Inc., 976 N.E.2d at 704; Miller Brewing Co., 903 N.E.2d at 68; Conn. Indem. Co., 652 N.E.2d at 883.

126. Indianapolis Downs, 834 N.E.2d at 703-04.

127. The decision in this case describes res judicata as comprised of two branches: claim preclusion and issue preclusion, as many cases do. Robertson, 65 N.E.3d at 1050; see, e.g., Indianapolis Downs, 834 N.E.2d at 703. However, other courts have treated res judicata as synonymous with claim preclusion, and treated issue preclusion (aka collateral estoppel) as a separate but related doctrine. See, e.g., Thrasher Buschmann \& Voelkel, P.C. v. Adpoint, Inc., 24 N.E.3d 487, 494 (Ind. Ct. App. 2015); Conn. Indem. Co., 652 N.E.2d at 882. Because courts sometimes use the phrase "res judicata" to refer exclusively to claim preclusion, and sometimes to refer to both claim and issue preclusion, confusion can arise regarding the legal effect of "res judicata." Courts in other jurisdictions have acknowledged the same confusion resulting from inconsistent use of terminology, and elected to avoid the use of the phrase "res judicata" in favor of specifying either claim preclusion or issue preclusion. See, e.g., DKN Holdings, LLC, v. Faerber, 352 P.3d 378, 386 (Cal. 2015). 
IDOI's action was ultra vires and void. ${ }^{128}$ The court of appeals disagreed. Relying on the Indiana Supreme Court's decisions in Indiana Department of Environmental Management v. Twin Eagle LLC $C^{129}$ and Johnson v. Celebration Fireworks, Inc., ${ }^{130}$ the court of appeals explained that exhaustion may still be required even when a complaint alleges the unconstitutionality of a statute, because the administrative action may resolve the case on other grounds without confronting broader legal issues. ${ }^{131}$ Quoting Twin Eagle, the court of appeals explained that an administrative agency ordinarily "must resolve factual issues before the trial court acquires subject matter jurisdiction." 132 Nevertheless, the court noted that exhaustion is not required if a statute is void on its face, or if an action is brought upon the theory that an agency lacks jurisdiction to act in a particular area. ${ }^{133}$

The court of appeals concluded that because there is no claim that IDOI lacked jurisdiction or the general authority to investigate the type of claim at issue, the exceptions to the exhaustion requirement did not apply. ${ }^{134}$ The court instead found that the timeliness of the IDOI's order was a fact-sensitive question that should have been addressed at the agency first, not through a declaratory judgment action or action for prohibition and mandate. ${ }^{135}$ The court concluded that FATIC had an administrative remedy and was required to pursue it. ${ }^{136}$ This remedy failed due to FATIC's failure to timely file the administrative record, and res judicata prevented FATIC from taking a second bite at the apple. ${ }^{137}$

3. Relationship Between Failure to Exhaust and Subject Matter Jurisdiction.-As noted above, the court of appeals stated in the most recent Robertson decision that the trial court does not acquire subject matter jurisdiction until an administrative agency resolves factual issues, quoting earlier precedent. ${ }^{138}$ This statement warrants comparison with the court of appeals' statement in the first Robertson case that failure to exhaust raises a procedural error, not a jurisdictional one, and is therefore an error that can be waived. ${ }^{139}$ As noted above,

128. Robertson, 65 N.E.3d at 1050, 1052.

129. 798 N.E.2d 839, 844 (Ind. 2003).

130. 829 N.E.2d 979, 983 (Ind. 2005).

131. Robertson, 65 N.E.3d at 1052.

132. Id. (quoting Twin Eagle LLC., 798 N.E.2d at 844). On transfer of the previous case, the supreme court had summarily upheld the portion of the first court of appeals decision finding that IDOI's exhaustion of administrative remedies claim was waived, First Am. Title Ins. Co. v. Robertson, 19 N.E.3d 757 (Ind. 2014), as the court of appeals explained in the present case. Robertson, 65 N.E.3d at 1048.

133. Id.

134. Id. at 1053.

135. Id.

136. Id.

137. Id. at 1054 .

138. Id. at 1052 .

139. First Am. Title Ins. Co. v. Robertson ex rel. Ind. Dep't of Ins., 990 N.E.2d 9, 12-13 (Ind. Ct. App. 2013). 
the supreme court had summarily upheld the portion of the first court of appeals' finding on this issue. ${ }^{140}$

Like the earlier Roberson cases, another 2017 case, Smith v. Butts, ${ }^{141}$ found that failure to exhaust is a procedural error that does not deprive the court of subject matter jurisdiction. That case involved the $\$ 1983$ claim by an inmate (Smith) against the Indiana Department of Correction ("DOC") based on the DOC's alleged failure to timely mail Smith's motion for extension of time to file a petition for certiorari to the U.S. Supreme Court. ${ }^{142}$

Several days prior to the deadline of his petition for certiorari, Smith had given officials working at the DOC in various offices, including the law library and the mail department, ("Officials") a motion for extension of time. ${ }^{143}$ A few days later he gave the Officials the petition, but two days prior to the original due date (not accounting for any extensions), he requested the petition back to make corrections. ${ }^{144}$ Subsequently, Smith gave the Officials the corrected petition to be mailed. ${ }^{145}$

After receiving a letter from the Clerk of the U.S. Supreme Court notifying Smith that his case had been dismissed due to the untimely filing of the petition for certiorari, Smith filed two formal grievances against the DOC. ${ }^{146}$ DOC grievance procedures must be filed within twenty days of the incident. ${ }^{147}$ Smith's grievances were filed more than twenty days after the DOC allegedly failed to file his mail on time, but less than twenty days after receipt of the supreme court Clerk's letter. ${ }^{148}$ The DOC denied Smith's grievances on grounds of untimeliness and because it determined that Smith should have consulted with the law library staff to determine if he could seek relief under the "mailbox rule."149 Smith then filed a $\$ 1983$ claim against the Officials in Henry County Circuit Court, where both sides subsequently moved for summary judgment. ${ }^{150}$ The trial court denied Smith's motion and granted summary judgment in favor of the Officials, finding that it lacked subject matter jurisdiction due to Smith's failure to exhaust his administrative remedies. ${ }^{151}$

On appeal, the Indiana Court of Appeals found that the trial court erred in concluding that it was deprived of subject matter jurisdiction as the result of

140. First Am. Title Ins. Co. v. Robertson, 19 N.E.3d 757 (Ind. 2014); Robertson, 65 N.E.3d at 1048 .

141. 66 N.E.3d 967, 968-69 (Ind. Ct. App. 2016).

142. $I d$.

143. Id. at 969.

144. Id.

145. $I d$.

146. Id.

147. Id. at 971.

148. Id.

149. Id at 969 .

150. Id. at 970 .

151. Id. 
Smith's alleged failure to exhaust administrative remedies. ${ }^{152}$ Citing Alkhalidi $v$. Indiana Department of Corrections, 42 N.E.3d 562, 565 (Ind. Ct. App. 2015), ${ }^{153}$ the court explained that "[f]ailure to exhaust administrative remedies is a procedural error and does not give rise to a jurisdictional defect." ${ }^{154}$ The court further explained that failure to exhaust is an affirmative defense, which meant that the Officials had the initial burden of establishing Smith's failure to exhaust in summary judgment. ${ }^{155}$ The court ultimately found that questions of fact regarding whether Smith complied with the procedural rules governing the DOC grievance process as well as regarding the circumstances surrounding his request for the return of his petition for certiorari precluded summary judgment for either party. ${ }^{156}$ The court of appeals therefore upheld the trial court's denial of summary judgment in favor of Smith, and reversed its grant of summary judgment in favor of the Officials. ${ }^{157}$

\section{STANDARD OF REVIEW}

Under AOPA, Indiana Code section 4-21.5-5-14(d), an appellate court will set aside an agency's action if it is:

(1) arbitrary, capricious, an abuse of discretion, or otherwise not in accordance with law;

(2) contrary to a constitutional right, power, privilege or immunity;

(3) in excess of statutory jurisdiction, authority, or limitations, or short of statutory right;

(4) without observance of procedure required by law; or

(5) unsupported by substantial evidence. ${ }^{158}$

In the latest iteration of cases challenging Indiana's liquor, wine, and beer distribution system, Indiana Alcohol and Tobacco Commission v. Spirited Sales,

152. Id.

153. Alkhalidi was discussed in detail in the 2016 survey article. See Balzer \& Herceg, supra note 107, at 930-31. Alkhalidi relied on the Indiana Supreme Court's 2014 decision in First Am. Title Ins. Co. v. Robertson, 19 N.E.3d 757, 760 (Ind. 2014), amended on reh'g, 27 N.E.3d 768 (Ind. 2015), for the principle that failure to exhaust is a procedural error that does not implicate subject matter jurisdiction.

154. Smith v. Butts, 66 N.E.3d 967,970 (Ind. Ct. App. 2016); see also Herceg \& Balzer, supra note 107, at 116-17 (noting that the Indiana Court of Appeals had reached opposite conclusions regarding whether failure to exhaust implicates subject matter jurisdiction in its decisions in Ellis v. State, 58 N.E.3d 938 (Ind. Ct. App. 2016) and Bragg v. Kittle’s Home Furnishings, Inc., 52 N.E.3d 908 (Ind. Ct. App.), trans. denied, 62 N.E.3d 1201 (Ind. 2016)).

155. Smith, 66 N.E.3d at 970.

156. $I d$. at 972 .

157. Id.

158. IND. CODE $\S 4-21.5-5-14$ (d) (2017). 
$L L C^{159}$ presents an application of this familiar standard of review in the context of nuanced statutory and constitutional arguments. Of particular interest, Spirited Sales addressed the arbitrary and capricious standard in the context of agency action that was allegedly inconsistent with the agency's prior actions.

Almost five years ago, Spirited Sales began its journey by applying to the Indiana Alcohol and Tobacco Commission ("ATC") for a liquor wholesaler's permit. ${ }^{160}$ Before delving into the specifics of the legal arguments at issue, it is important to note a few key facts about Spirited Sales itself, and particularly its corporate structure and related parties. Spirited Sales is a limited liability company registered in Delaware, and is wholly owned by a parent company, E.F. Transit, Inc. ("EFT"). ${ }^{161}$ EFT transports wine, beer, and liquor throughout Indiana. EFT is owned by five shareholders who just happen to be the same five who own Monarch Beverage Company, Inc. ("Monarch"). ${ }^{162}$ Monarch is an Indiana company that holds a beer and wine wholesaler's permit. Importantly,

Indiana has an alcoholic beverage regulatory system, dividing distribution into three distinct tiers - manufacture, wholesale, and retail. Within each tier, licenses are issued separately ... . [and] a pair of provisions [in Indiana's regulations] prohibit[] the holder of a beer wholesaler's permit from having an interest in a liquor wholesaler's permit, and vice-versa . . . ${ }^{163}$

The administrative law judge, after holding a hearing, recommended denial of Spirited Sales' application and issued findings of fact and conclusions of law. He noted that "despite some separation of business formalities, EFT and Monarch "operated as the same company" and also noted "that a liquor wholesaler like Spirited, 'entering into a contract with EFT, would in reality be entering into a contract with Monarch." 164 The ATC adopted the proposed findings and conclusions, and Spirited Sales filed a petition in Marion Superior Court seeking judicial review. ${ }^{165}$ The trial court set aside the Commission's order and directed the Commission to issue Spirited Sales a liquor wholesaler's permit. ${ }^{166}$ In doing so, the trial court "found that, in light of previous Commission decisions that cited to the corporate separateness doctrine in support of granting a permit to businesses whose owners held interests prohibited by statute, the Commission's denial of Spirited's application . . . was arbitrary and capricious." 167 The commission appealed and concurrently sought a stay from both the trial court and

159. 79 N.E.3d 371 (Ind. 2017).

160. Id at 374 .

161. Id.

162. Id.

163. Id. (internal citations and footnotes omitted).

164. Id.

165. Id. at 375 .

166. Id.

167. Id. 
the court of appeals, both of which were denied. ${ }^{168}$ The ATC then filed motions seeking emergency transfer to the supreme court and a stay of the trial court's order. ${ }^{169}$ The supreme court granted the ATC's motion for transfer and denied its motion to stay. ${ }^{170}$

The issue before the supreme court was stated simply: "[W] hether a privately held limited liability company may be granted a liquor wholesaler's permit, pursuant to Title 7.1 of the Indiana Code, when it is wholly owned by another company, which shares directors, officers, and all shareholders with the holder of a beer wholesaler's permit." ${ }^{\prime 11}$ In evaluating this issue, the court referenced the familiar standard for reviewing an administrative decision established by Indiana Code section 4-21.5-5-14(d). ${ }^{172}$ The burden is on Spirited Sales to prove the agency action is invalid for one of these reasons, and the court noted its limitations, "recogniz[ing] an agency['s] . . expertise in its field." 173

Spirited Sales contended that the ATC's "unexplained departure from its own long-standing precedent demonstrates that its denial was arbitrary and capricious." ${ }^{174}$ The court disagreed.

First, the court addressed the statutory basis for the ATC's denial of Spirited Sales' application, finding that the applicable statute is "clear on its face and the Commission followed the statute's unambiguous language." 175 In evaluating Spirited Sales' argument, the court looked to well-established guidance on statutory interpretation. Looking at the "plain language of the statute, giving its words their ordinary meaning and considering the structure of the statute as a whole" 176 the court noted that the relevant statutes have developed a scheme where there is a tiered system of manufacturers, wholesalers and retailers, with rules for the operation and interaction of each ${ }^{177}$ All of this, the court noted, is tied to the purpose of the statute, which is " $[\mathrm{t}] \mathrm{o}$ protect the economic welfare, health, peace, and morals of the people of this State . . . [and][t]o regulate and limit the manufacture, sale, possession, and use of alcohol and alcoholic beverages." ${ }^{178}$ Part of the legislature's approach to accomplishing this purpose was, in part, to implement "both vertical and horizontal interest segregation" where in vertical segregation "entities operating in one tier may not, absent limited exceptions, hold an 'interest' in a permit to operate in another tier." 179 Title 7.1 also has other restrictions limiting relationships between entities. Central

168. Id.

169. Id.

170. Id.

171. Id. at 375-376.

172. Id. (citing IND. CODE $\S 4-21.5-5-14(\mathrm{~d})(2017)$ ).

173. Id.

174. Id. at 377 .

175. Id.

176. Id. at 376 (citing West v. Office of Ind. Sec'y of State, 54 N.E.3d 349, 353 (Ind. 2016)).

177. Id at 377 .

178. Id. (citing IND. CoDE $§ 7.1-1-1-1(2017))$.

179. Id. 
to the issue before the court was the definition of a "holder" and the meaning of "interest." Section "7.1-5-9-6 makes it 'unlawful for the holder of a distiller's, rectifier's, or liquor wholesaler's permit to have an interest in a beer permit of any type." "180 This "prohibited interest" law was at the base of the ATC's decision to deny Spirited Sales' application for a liquor wholesaler's permit.

The court viewed these statutes as clear on their face and that Monarch is a "holder" of a beer wholesaler's permit, and that "interest" is read broadly to "achieve a broader prohibition." 181 In its evaluation of the application, the ATC examined the business dealings of Spirited Sales and Monarch. The findings supported the ATC's denial of the application under the plain language of the statute, according to the court. Specifically, the court observed that Spirited Sales and Monarch's business relationships violated the prohibited interests statutes through Spirited Sales' sole member, EFT. The court held that "ties between EFT and Monarch were so extensive that EFT could reasonably be deemed to hold an interest in a beer wholesaler's permit - an interest prohibited by a combined reading of sections 7.1-5-9-6 and 7.1-1-2-5."182 The court listed several of the connections between the parties, including:

Monarch's management created EFT to take advantage of certain favorable tax regulations ... EFT helps Monarch distribute alcoholic beverages by receiving and warehousing products, managing inventory, sorting and delivering, and collecting invoices. Monarch . . . serves as EFT's guarantor, is EFT's primary customer [and the parties] share a CEO, a board of directors, and many employees. ${ }^{183}$

So with this information, and after a thorough review of the relevant statutes, the court held that ATC's denial of a liquor wholesaling permit to Spirited Sales was within its statutory authority and that "Monarch, as the holder of a beer wholesaler's permit, was prohibited from holding an interest in a liquor wholesaler's permit."

Turning to whether the ATC's decision was arbitrary or capricious, the court relied on the plain language of the applicable statutes. Spirited Sales argued that the ATC's decision was arbitrary and capricious because of apparent inconsistencies with its own precedent. ${ }^{184}$ Yet the court disagreed, explaining that even if there was a departure from the agency's precedent, "prior inconsistent actions are irrelevant"185 for a determination of whether a decision was arbitrary or capricious. The court explained that "[i]f the basis for denial is a failure to meet a requirement of the governing ordinance, albeit one previously enforced laxly or not at all, the inquiry is not whether there are prior inconsistent decisions, but rather whether there is substantial evidence supporting the agency's

180. Id. (citing IND. CoDE $§ 7.1-5-9-6$ (2017)).

181. Id. at 377-78.

182. Id. at 379 .

183. Id.

184. Id. at 380.

185. Id. 
decision." 186 The court found that the ATC met the substantial evidence requirement, reasoning that because the ATC's decision was "grounded in statutory language that is clear on its face, therefore it cannot be said that there was no reasonable basis for the action." 187

Spirited Sales put forth several alternative theories in support of its position. Namely, Spirited Sales argued that the ATC's denial was based on political grounds, was in violation of the Indiana Constitution's Equal Privileges and Immunities Clause, and that its decision violated the Due Process Clause of the Indiana and U.S. Constitutions. ${ }^{188}$ Again, the court disagreed.

The court dismissed Spirited Sales' "political grounds" argument in short order, noting that "political grounds" has a narrow meaning including denials based only on "patronage" or "political affiliation." 189 There was no basis for such an argument. The court observed:

While the trial court cites communications from a 2009 proceeding involving EFT, those proceedings occurred under a gubernatorial administration other than the one in control when Spirited's permit was denied. Furthermore, most of the key people involved in the 2009 communications were no longer with the governor's office by the time the application was filed in 2013. By the time the Commission voted on Spirited's application ... the Executive secretary was new and only one commissioner remained from the prior administration. ${ }^{190}$

Next, the court addressed Spirited Sales' argument that the ATC's decision violated the Equal Privileges and Immunities Clause of the Indiana Constitution. Spirited Sales based its argument on the fact that in prior cases, the ATC "engaged in preferential treatment by recognizing corporate separateness for some companies, but not for others." ${ }^{\text {91 }}$ Yet, the Equal Privileges and Immunities Clause can be violated when disparate treatment is not "reasonably related to inherent characteristics which distinguish the unequally treated classes" ${ }^{192}$ or when preferential treatment is 'not uniformly applicable and equally available to all persons similarly situated." ${ }^{193}$ Spirited Sales argued and lost on the second prong because the court found that none of the entities that were in prior decisions where the ATC recognized corporate separateness were similarly situated to Spirited Sales.

Finally, the court rejected the argument that the ATC's decision violated the

186. Id. at 380 (quoting Equicor Dev., Inc. v. Westfield-Washington Twp. Plan Comm'n, 758 N.E.2d 34, 38 (Ind. 2001) (emphasis in original)).

187. $I d$.

188. Id. at 381 .

189. Id.

190. Id.

191. Id. at 382 .

192. Id. (citing Myers v. Crouse-Hinds Div. of Cooper Indus., Inc., 53 N.E.3d 1160, 1165

(Ind.), reh'g denied, 53 N.E.3d 1173 (Ind. 2016)).

193. Id. 
Due Process Clause of the Indiana or U.S. Constitutions. The hearing was fair, and Spirited Sales had no "deprivation of cognizable property or liberty interest" 194 because the issuance or revocation of a permit is "within the power of the Legislature to prescribe." 195

In conclusion, the thread running through the court's evaluation of all of Spirited Sales' arguments, and its decision to reverse the trial court's decision was that the ATC's "denial was tethered to the mandates of the statute's unambiguous language and nothing else." 196

\section{JUDICIAL REVIEW PROCEDURES}

Brown v. Indiana Family \& Social Services Administration ${ }^{197}$ addressed the appropriate procedure upon judicial review when an agency decision does not contain necessary findings of fact. Ashley Brown was on Indiana's Hoosier Healthwise Program ("Program"), the state's Medicaid program, which is administered by MDWise, a "managed care entity administering Medicaid insurance coverage as a state contractor."198 Brown sought prior authorization under the Program seeking coverage for genetic testing following removal of a tumor in her abdomen and the identification of that tumor as paraganglioma, of which one-third to one-half are associated with inherited syndromes, including Hereditary Paraganglioma-pheochromocytoma ("PGL/PCC") Syndrome. ${ }^{199}$ The genetic testing "can identify individuals with PGL/PCC Syndrome"200 and "may improve patient prognosis through regular screening and treatment of early-onset malignancies." 201

MDWise denied Brown's prior authorization request because "genetic lab tests [were] not covered under Indiana Medicaid."202 Brown challenged the decision, first through MDWise's appeal procedures, which included a review of the decision by an "independent review organization" for the Indiana Department of Insurance. ${ }^{203}$ The independent reviewer agreed with MDWise, concluding that "the genetic testing was 'medically indicated' but that 'the genetic testing was correctly denied as it is not a covered benefit under the member's health plan.",204 Brown then sought an administrative appeal of MDWise's denial of the prior authorization. The presiding administrative law judge ("ALJ") sustained the

194. Id. at 382 .

195. Id. at 383.

196. Id.

197. 71 N.E.3d 50 (Ind. Ct. App. 2017).

198. Id. at 51 .

199. Id.

200. Id.

201. Id. (internal quotations omitted).

202. Id. (internal citation omitted).

203. $I d$.

204. Id. (internal citation omitted). 
denial. ${ }^{205}$ The ALJ concluded "that Indiana's Medicaid program did not cover genetic testing for PGL/PCC Syndrome and sustained the denial for prior authorization of the genetic test." ${ }^{206}$ The FSSA issued a final order upholding the ALJ's decision, and Brown sought judicial review. ${ }^{207}$

On review, Brown argued that the ALJ erred in sustaining the denial of her prior authorization of coverage for the genetic testing. ${ }^{208}$ The ALJ based her decision on the regulations excluding from coverage those services "that are not medically necessary." 209 "Medically necessary service" is reimbursable if it is "medically necessary, as determined by the office, which shall, in making that determination, utilize generally accepted standards of medical or professional practice" ${ }^{210}$ and "not be listed ... a as a noncovered service, or otherwise excluded from coverage." 211 The ALJ's decision that the testing is excluded rested on the fact that genetic testing was not covered in the IHCP manual and thus fell in the category of a service "otherwise excluded from coverage." 212

Notably, the FSSA conceded that the ALJ "erred in her legal reasoning and application of State Medicaid law" and that the testing Brown sought was not covered because it was new or experimental treatment, not because it is "otherwise excluded" from coverage. ${ }^{213}$ The FSSA argued that the proper remedy was to remand for a new factfinding hearing. ${ }^{214}$ The FSSA explained:

[T] he new or experimental provisions of [the relevant regulations] were not the legal basis for the ALJ's conclusion that the genetic testing was properly considered a noncovered service. And there was no factual finding regarding the genetic testing's status as a new or experimental treatment, e.g., its acceptance in the medical community or general concerns regarding its efficacy or safety. The status of the genetic testing at issue in this case may have now changed from being a new or experimental service, to a medically accepted service, but in order to determine the status of the genetic testing at issue in this case, there must be a rehearing of the relevant evidence. ${ }^{215}$

Brown contended that FSSA was attempting to raise a new issue that it did not properly preserve, and that remand was therefore improper pursuant to Indiana Code section 4-21.5-5-10, 11, and 12(a). ${ }^{216}$

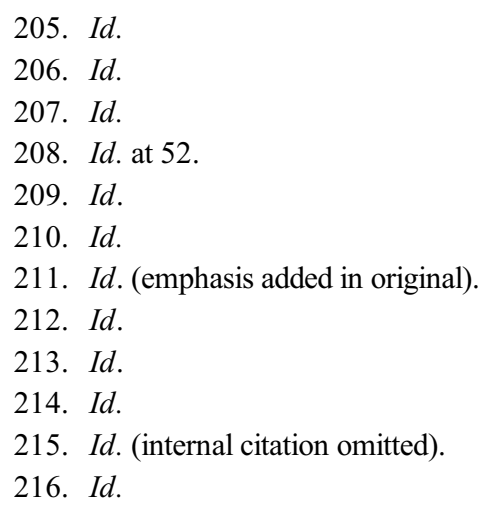


The court of appeals agreed with the FSSA. In so doing, the court explained that the statutes relied upon by Brown pertain to the scope of judicial review of facts and issues not raised before the agency. ${ }^{217}$ As such, these statutes are irrelevant to the propriety of remand to the agency. ${ }^{218}$ The court looked to Indiana Code section 4-21.5-5-12(b), which "provides that a court may remand a matter to the agency before final disposition of a petition for review with directions that the agency conduct further factfinding or that the agency prepare an adequate record, if [ ] the agency failed to prepare or preserve an adequate record." ${ }^{219}$ That was precisely the case and the court determined that remand was appropriate.

\section{JURISDICTION}

In all instances, an agency must have jurisdiction to render a decision. Typically, when agency jurisdiction is litigated, the agency has exercised jurisdiction and such exercise is subsequently challenged on appeal. Duke Energy Indiana, LLC v. Town of Avon ${ }^{220}$ involves the opposite fact pattern: the agency had refused to exercise jurisdiction and this refusal was challenged on appeal. This case arose from Duke's challenge to an ordinance passed by the Town of Avon that required Duke, an electricity supplier and public utility under Indiana law, to "remove, at Duke's own cost, utility poles, power lines, and other equipment located either on land owned by Avon or in Avon's rights-of-way."221 Duke informed Avon that it would not comply with the ordinance. ${ }^{222}$ In response, Avon filed a complaint in the Hendricks County Circuit Court against Duke seeking declaratory and injunctive relief alleging that, "Indiana law requires a utility provider that must relocate facilities to accommodate a municipal improvement to do so without reimbursement from the municipality." ${ }^{, 23}$ Duke disagreed and filed a motion to stay the Hendricks Circuit Court action and a complaint with the Indiana Utility Regulatory Commission ("IURC").

In its Complaint, Duke argued that statutory and case law provide that utilities must relocate their facilities at their own expense only in cases where they are located in the right-of-way and are part of a general road improvement project. ${ }^{224}$ Because this case involved a multi-use trail, Duke contended that Avon must pay for the relocation of Duke's facilities. Duke also argued that the IURC had exclusive jurisdiction over this matter. ${ }^{225}$

The IURC initially declined to set a procedural schedule because the same action was pending before the Hendricks County Circuit Court and ordered the

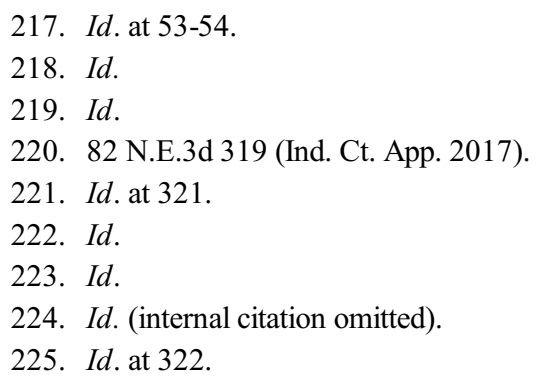


parties to update the IURC regarding the status of the state court proceedings. ${ }^{226}$ After Duke and Avon entered into a settlement agreement in the Hendricks County Circuit Court case allowing Duke to pursue a ruling from the IURC, the IURC presiding officers entered an order denying Duke's request for an attorneys' conference. ${ }^{27}$ The presiding officers explained that because the Ordinance did not contain any fee requirements, it did not raise questions that required the IURC's specialized expertise. ${ }^{228}$ The issue at hand-the reasonableness of the Ordinance - was a general legal question that may be raised before a trial court.

Duke appealed this ruling to the full commission, which upheld the decision of the presiding officers and dismissed Duke's complaint without prejudice. ${ }^{229}$ Duke appealed the IURC's decision.

The court of appeals disagreed with the IURC and held that Indiana Code section 8-1-2-101(a)(1) and section 115 "unambiguously establish exclusive jurisdiction in the IURC to hear Duke's complaint on the validity of Avon's ordinance." ${ }^{230}$ This case presents, at its essence, an issue of statutory interpretation of whether an agency possesses jurisdiction over a matter and that is "a question of law for the courts" and "lies squarely within the judicial bailiwick." " ${ }^{231}$ In reaching its decision, the court looked no further than the statute at issue. "Section 115 explicitly says that it 'shall be [the IURC's] duty' to "enforce . . . all . . . laws[] relating to public utilities." ${ }^{332}$ It also provides that the IURC shall " "inquire into any . . . violation' of a local ordinance by a public utility.",233

The court acknowledged the IURC's assessment that (at least at that point in the proceedings), the case involved a "general legal question" rather than one requiring specific expertise to resolve. However, the court determined that granting the IURC exclusive jurisdiction prevents Indiana's public utilities from being "forced to engage in a multitude of disputes over local ordinances throughout the State with no clear guidance either to the utilities or the municipalities." ${ }^{234}$ The court agreed with the position of the amici curiae, ${ }^{235}$ who opined that the IURC has a "strong understanding of the public interest" and "its demonstrated expertise in administering the regulatory schemes in which utilities operate are essential to a fair evaluation of local ordinances that impact

226. $I d$.

227. Id. at 323 .

228. Id.

229. Id. at 324 .

230. Id. at 325 .

231. Id. at 324 (internal citations and quotations omitted).

232. Id at 325 .

233. Id. (emphasis in original) (internal quotations omitted).

234. Id.

235. Amici included the Indiana Energy Association and the Indiana Chapter National Association of Water Companies, both of which represent utilities. 
utilities. ${ }^{236}$

\section{AGENCY RULEMAKING AUTHORITY}

Agency rulemaking authority is subject to certain limitations. The agency can only exercise the power delegated to it by statute, and the legislature can only delegate rulemaking power if the delegation is accompanied by sufficient standards to guide the agency in the process. Gunderson v. State ${ }^{237}$ illustrates these limitations in the context of the public trust doctrine.

Gunderson is a landmark decision with far-reaching implications on constitutional law, real property, environmental law, and of course, administrative law. The importance of the decision's impact on preservation of the rights of Hoosiers to access the lands under the navigable waters held in trust for them by the State of Indiana cannot be understated. Though this Article will primarily focus on the decision's impact to administrative law, the decision could (and should) also be dissected and analyzed extensively for its other important components.

The decision first and foremost reaffirmed the century-old principle that the State "owns and holds 'in trust' the lands under navigable waters within its borders, 'including the shores or space between ordinary high and low water marks, for the benefit of the people of the state." ${ }^{238}$ The key issue in the case was how to identify "the precise boundary at which the State's ownership interest ends and the private property interest begin." ${ }^{239}$

The case was a quiet title action brought by the Gundersons, who owned lakefront property along Lake Michigan in Long Beach, Indiana. ${ }^{240}$ The action was brought in response to a 2010 ordinance passed by the Town of Long Beach ("Town") adopting the administrative boundary which separates state-owned beaches from private, upland portions of the shore as established by a rule promulgated by the Indiana Department of Natural Resources ("DNR"). ${ }^{241}$ The rule ("OHWM Rule") in its entirety provides as follows:

\section{IAC 1-1-26 “Ordinary high watermark" defined}

Sec. 26. "Ordinary high watermark" means the following:

(1) The line on the shore of a waterway established by the fluctuations of water and indicated by physical characteristics.

Examples of these physical characteristics include the following:

(A) A clear and natural line impressed on the bank.

(B) Shelving.

236. $I d$.

237. 90 N.E.3d 1171 (Ind. 2018).

238. Id. at 1173 .

239. Id.

240. Id.

241. Id. at 1174 . 
(C) Changes in character of the soil.

(D) The destruction of terrestrial vegetation.

(E) The presence of litter or debris.

(2) Notwithstanding subdivision (1), the shore of Lake Michigan at five hundred eighty-one and five-tenths (581.5) feet I.G.L.D., 1985 (five hundred eighty-two and two hundred fifty-two thousandths (582.252) feet N.G.V.D., 1929). ${ }^{242}$

The Ordinance specifically adopted Subsection (2) of the rule. ${ }^{243}$

In response to the Ordinance, the Gundersons and other lakefront property owners filed suit against the Town. ${ }^{244}$ That lawsuit has been held in abeyance after the court of appeals ruled that the State was a necessary party. ${ }^{245}$ The Gundersons then filed the present dispute against the State and DNR (collectively "State"), seeking a declaratory judgment on the extent of their property rights along the shoreline and to quiet title on their land. ${ }^{246}$ Petitions to intervene were granted for the Alliance for the Great Lakes and Save the Dunes and the Long Beach Community Alliance (collectively, "Intervenors"). ${ }^{247}$

All parties moved for summary judgment. ${ }^{248}$ The Gundersons argued that "there is no public trust right in any land abutting Lake Michigan." 249 The State argued that Indiana owns the disputed beach in trust for public use, and the Intervenors argued that the State owns the disputed shore of Lake Michigan below the ordinary high water mark ("OHWM") in trust for public recreational use. $^{250}$

The trial court entered summary judgment in favor of the State and the Intervenors, determining that the State holds legal title in public trust to the land below the OHWM as defined by DNR's rule. ${ }^{21}$ The trial court further held that to the extent there is overlap between the Gunderson's land and the State's property interest, the Gundersons cannot unduly impair the protected rights of and uses of the public, including the public's right to use the beach below the OHWM for commerce, navigation, fishing, recreation, and other related activities, including but not limited to boating, swimming, sunbathing, and other beach sport activities. ${ }^{252}$ The court of appeals reversed in part and remanded in part,

242. 312 Ind. Admin. Code 1-1-26 (2017).

243. Gunderson, 90 N.E.3d at 1178; see also LBLHA, LLC v. Town. of Long Beach, 28 N.E.3d 1077, 1080-81 (Ind. Ct. App. 2015).

244. Gunderson, 90 N.E.3d at 1174.

245. Id. at 1174 n.1 (citing LBLHA, LLC, 28 N.E.3d at 1091).

246. Id.

247. $I d$.

248. $I d$.

249. Id.

250. Id.

251. Id. at 1174-75.

252. Id. at 1175 . 
finding that the Gunderson's property extended to the ordinary low water mark, subject to the rights of the public use rights up to the OHWM, such as walking along the beach and gaining access to the public waterway. ${ }^{253}$ The court of appeals also determined that DNR's administrative boundary is invalid and that the OHWM remains defined by the common law public trust doctrine. ${ }^{254}$

All parties submitted petitions to transfer, which were granted in June 2017. ${ }^{25}$ On transfer, the Indiana Supreme Court explained that the basic controversy presented by the case "is whether the State holds exclusive title to the exposed shore of Lake Michigan up to the OHWM, or whether the Gundersons, as riparian ${ }^{256}$ owners, hold title to the water's edge, thus excluding public use of the beach." 257 Though all parties agreed that the land below Lake Michigan's OHWM is held in trust for public use, the parties did not agree regarding the precise location of the OHWM; i.e., whether it is wherever the water meets the land at any given moment (as the Gundersons argued) or whether the boundary is further landward and includes a portion of exposed shore. ${ }^{258}$

The court explained that the case required a two-part analysis. ${ }^{259}$ First, as a matter of federal law, the court needed to determine the boundary of the bed of Lake Michigan that originally passed to Indiana at statehood in 1816. After examining in detail the history of the public trust doctrine, the court concluded that "absent evidence of an express federal grant before 1816, the shore lands below Lake Michigan's OHWM were not available for conveyance to private parties." ${ }^{260}$ As for what the OHWM itself entailed, the court rejected the Gunderson's argument that the OHWM means only the lands underneath navigable waterways. ${ }^{261}$ The court observed various precedents that described the OHWM in similar ways, such as including both the "shore and submerged soil," public lands "bordering on or bounded by navigable waters," the "shore between high and low water mark, as well as the bed of the river," "the land between the edge of the water of Lake Michigan and the ordinary high water mark," and "including the shores or space between the ordinary high and low water marks." ${ }^{262}$ The court noted that these are all alternative expressions of the same law: lands on the on the water body side of the OHWM pass to new states as an incident of sovereignty, whereas lands on the upland side of the OHWM are

253. $I d$.

254. Id.

255. Id.

256. Id. As the court explained, technically the correct term is "littoral" because the Gundersons own lakefront property, not riverfront property, but because the term "riparian" is the term commonly used to describe the rights of both types of owners, that is the term used for purposes of this decision. Id. at 1174-75.

257. Id. at 1175 .

258. Id.

259. Id. at 1175-76.

260. Id. at $1178-79$.

261. Id. at 1179 .

262. Id. at 1180 . 
available for federal patent and private ownership. ${ }^{263}$

The second step of the analysis was a matter of state law: the court needed to determine whether Indiana has relinquished its title to the shores and submerged lands of Lake Michigan. ${ }^{264}$ The court rejected various arguments proffered by the Gundersons, ${ }^{265}$ and noted that "even if the legislature had intended to extinguish public trust rights in the shores of Lake Michigan, it lacked the authority to fully abdicate its fiduciary responsibility over these lands." ${ }^{266}$

Of particular concern for purposes of this Article was the Gunderson's last argument: that DNR had no authority to establish or alter property boundaries or to acquire property rights by administrative definition of the OHWM, specifically Subsection 2 of DNR's OHWM Rule, which sets the OHWM for Lake Michigan at a set elevation. ${ }^{267}$ Intervenors made the same argument for a different reason: they were concerned that providing such power to DNR threatens to alienate public trust lands. ${ }^{268}$ The State responded that it has statutory authority over navigable waters and contiguous lands. ${ }^{269}$ The State also argued that relying only on a common-law physical characteristics test would lead to uncertainty regarding the boundary of riparian landowners and the extent of DNR's jurisdiction, and that it is therefore practical to have an administrative boundary. ${ }^{270}$ The court's decision does not reflect a challenge to Subsection (1) of the OHWM Rule, (which establishes the OHWM by physical characteristics test), and the court indicated that this subsection was consistent with the traditional common-law OHWM. ${ }^{271}$

With respect to Subsection (2) of the OHWM Rule, the court sided with the Gundersons and the Intervenors. ${ }^{272}$ The court explained that the legislature cannot delegate to an administrative agency the power to make a law, and that it can only delegate rulemaking power if the delegation is accompanied by sufficient

263. Id.

264. Id. at 1182 .

265. The court specifically rejected the Gundersons' arguments that Indiana relinquished its title by virtue of the Lake Preservation Act, IND. CODE § 14-26-2-5, which is intended to recognize "the public's right to preserve the natural scenic beauty of our lakes and to recreational values upon the lakes" and "does not apply" to Lake Michigan. Id. at 1181-83. The court explained that stating that the Act "does not apply" to Lake Michigan does not equate to an express abrogation of the common-law public trust doctrine. Id. The court also rejected the Gunderson's argument that Bainbridge v. Sherlock, 29 Ind. 364 (1868) was evidence of relinquishment. The court noted that the case has "received sharp criticism from contemporary legal commentators," and noted that "whatever the merits" of its premises, they have no application outside questions of riparian title along the Ohio River. Id. at 1183-84 n. 9.

266. Id. at 1183 (emphasis in original).

267. Id. at 1185 .

268. Id.

269. Id.

270. Id.

271. Id.

272. Id. at 1186 . 
standards to guide the agency in the process. ${ }^{273}$ The court expressed the same concern voiced by the Intervenors: that DNR cannot change the OHWM, as such a change could threaten to alienate public trust lands. ${ }^{274}$ Quoting a 1950 Indiana Supreme Court case, the court stated that " $[t]$ he state in its sovereign capacity is without power to convey or curtail the right of its people in the bed of Lake Michigan." 275

The court criticized Subsection 2 of DNR's OHWM definition because the OHWM is a moveable boundary. ${ }^{276}$ Yet setting the OHWM at a set elevation results in a static boundary that does not take into account the effect of accretion and erosion. ${ }^{277}$ If accretion and erosion are not considered, the result could be either a diminution of public trust lands or an uncompensated taking, the court found. ${ }^{278}$ Nevertheless, the court recognized that having an administrative OHWM definition served other valid purposes, such as establishing a jurisdictional benchmark for administering regulatory programs by the DNR and the U.S. Army Corps of Engineers, so the court "stop[ped] short of declaring it void." 279 The court ultimately held that "the natural OHWM is the legal boundary separating State-owned public trust land from privately-owned riparian land."280

Lastly, the court addressed the question of what activities are protected within the OHWM. ${ }^{281}$ The court concluded that, "at a minimum, walking below the OHWM along the shores of Lake Michigan is a protected public use in Indiana." 282 The court noted that in the absence of a statutory framework of public trust rights it retains the common law power to articulate and expand the scope of protected uses ${ }^{283}$ It further stated that "a broad interpretation of protected uses accords with the view among courts that the "trust doctrine, like all common law principles, should not be considered fixed or static, but should be molded and extended to meet changing conditions and need of the public it was created to benefit." 284 Nevertheless, the court determined that the separation of powers compelled it to exercise judicial restraint, and therefore it concluded that any enlargement of the public rights should be left to the more representative lawmaking procedures of the other branches of government. ${ }^{285}$

273. Id.

274. Id.

275. Id.

276. $I d$.

277. Id. at 1187 .

278. Id.

279. $I d$.

280. Id. at 1188 .

281. Id. at 1187 .

282. Id. at 1188 (emphasis in original).

283. Id.

284. Id. (quoting People ex rel. Scott v. Chicago Park Dist., 360 N.E.2d 773, 780 (Ill. 1976)

(quoting Borough of Neptune City v. Borough of Avon-By-The Sea, 294 A.2d 47, 54 (N.J. 1972))).

285. Id. at 1188-89. 


\section{CONCLUSION}

This survey Article represents but a fraction of the administrative law decisions issued by Indiana's appellate courts in the last year. These issues are complex and ever-evolving and demonstrate the important impact such agencies have on many aspects of our daily lives. 